\title{
Osseous Pathological Changes in the White-Tailed Eagle (Haliaeetus albicilla) in its Central European Habitat
}

\author{
Marcin Komosa $^{1}$, Jan Włodarek ${ }^{2 *}$, Hieronim Frąckowiak ${ }^{1}$, Maciej Zdun ${ }^{1}$, \\ Anna Charuta ${ }^{3}$, Maciej Gogulski ${ }^{4}$, Tadeusz Mizera ${ }^{5}$ \\ ${ }^{1}$ Department of Animal Anatomy, Faculty of Veterinary Medicine and Animal Sciences, \\ Poznań University of Life Sciences, Poznań, Poland \\ ${ }^{2}$ Department of Preclinical Sciences and Infectious Diseases, Faculty of Veterinary Medicine and Animal Sciences, \\ Poznań University of Life Sciences, Poznań, Poland \\ ${ }^{3}$ Department of Vertebrates Morphology, University of Natural Sciences and Humanities, Siedlce, Poland \\ ${ }^{4}$ University Center of Veterinary Medicine, Poznań University of Life Sciences, Poznań, Poland \\ ${ }^{5}$ Institute of Zoology, Faculty of Veterinary Medicine and Animal Sciences, \\ Poznań University of Life Sciences, Poznań, Poland
}

Received: 29 June 2017

Accepted: 11 February 2018

\begin{abstract}
The aim of our research was to examine bone health in white-tailed eagles (Haliaeetus albicilla) that died in the years 2010-2016. The research was conducted on 37 complete skeletons of eagles that came from the territories of Poland and Germany. CT and digital radiography were used in the research, and anatomical and histological analyses were carried out. We described macroscopic bone lesions in 14 birds. The most frequently found forms of pathological changes were osteophytes, which formed mainly in pelvic limbs. They were found less frequently in certain wing bones, as well as the clavicle and the sternum. In four cases, proliferative bone lesions were accompanied by osteoarthritis. Osteochondritis dissecans (OCD) was diagnosed in six birds, including one in the early stages of the disease. The lesions were found in most cases in the knee joint area and affected mainly the proximal epiphysis of the tibiotarsal bone. In one bird, a macroscopic presentation typical of osteomyelitis was observed on the tarsometatarsal bone, which might have been associated with its fracture and lysis. There was also one case of lesions typical of osteosarcoma. The analysis of individual bones of each skeleton revealed that bones from pelvic limbs more often underwent pathological changes, especially the tibiotarsus and associated joints. However, it is difficult to accept this observation as a rule without research on larger material. One cannot exclude the possibility that some types of changes in bones, such as osteosarcoma and OCD, may result from poisoning with heavy metals, particularly cadmium.
\end{abstract}

Keywords: white-tailed sea eagle, Haliaeetus albicilla, bone pathology, skeleton

*e-mail: wlodar@up.Poznań.pl 


\section{Introduction}

The population of the white-tailed eagle (Haliaeetus albicilla) in Central Europe has been increasing. Only a century ago, this bird species was on the verge of extinction with a very small population of 10-20 couples in the delta of the Oder River. At present, there are more than 1200 couples nesting in Central Europe [1-2]. A population increase has been observed in Poland, Germany, and in the countries of the Danube region [2-5]. However, the species status is still under scrutiny, which includes a cause-specific mortality analysis. Despite strict protection, many white-tailed eagles die due to human activity. Poisoning, both deliberate and accidental, is the most frequent cause of death [6]. White-tailed eagles die due to poisoning with heavy metals, mainly lead and polychlorinated biphenyls. One possible reason for lethal lead poisoning is that the eagles feed on birds of other species that have been hit by lead shot. Moreover, it has been found that white-tailed eagles were moderately intoxicated with cadmium, zinc, copper, manganese, and iron [7-9]. Since even moderate poisoning affects the bird's vitality, it may lead to poor health conditions, lower reproduction rates, and significantly limited capability of finding food, resulting in emaciation. Another possible outcome is metabolism disorders, which may lead to bone demineralisation and pathological lesions, including fractures [10-11].

Other frequent causes of eagle deaths are fractures caused by collisions with trains, cars, and power lines. Death by natural causes occurs much less frequently, i.e., in $10-18 \%$ of cases. Natural causes include territorial fights, age, or pressure from other large predators such as the eagle-owl. There are also cases of bacterial and fungal infections, and some causes remain unidentified $[9,12]$. A new kind of threat for all birds is wind turbines [13-15]. These very high constructions, with a rotor diameter larger than $40 \mathrm{~m}$, pose a mortal danger to birds if placed on their flight routes. The number of wind turbines in northern Germany, an area with a large population of white-tailed eagles, increased twofold in only five years. In 2000 , wind turbines produced $2.4 \%$ of the total energy in Germany. By 2003, at least 10 cases of lethal collisions with these constructions had been noted [16].

For the purpose of our research we examined the bones of white-tailed eagles that died in Poland in the years 2010-2016. The main aim was to present and describe the types of pathological osseous changes found. We were particularly interested in lesions that could be associated with factors other than incidental injuries that cause fractures, such as collisions. Hence, our research also aimed to assess the birds' health, i.e., their predisposition toward those diseases that manifest themselves in pathomorphological changes in bones. Our intention was also to indirectly show hypothetical environmental threats affecting the skeleton of white-tailed eagles and their survival capability. A morphological assessment of bones is all the more important as the organs typically examined in cases of poisoning are internal organs such as kidneys or liver, while the condition of bones in wild animals attracts less attention in scientific publications. Moreover, we hoped to show how bones responded to mechanical injuries in some of the animals. We were particularly interested in bone regeneration efficacy after collisions.

\section{Material and Methods}

The research was conducted on 37 birds that died of different, sometimes not fully established, causes. Some of the birds were found dead near train routes and power lines. Visual examination suggested collisions with a train or electric shock. Other birds were found in their natural habitat and transported to rehabilitation centres due to a bone fracture or poor health. Some of the animals were severely injured, presumably as a result of a fight with another white-tailed eagle. In other cases, the cause of the serious weakening could not be established, which may suggest poisoning or disease. The birds had to be euthanized in rehabilitation centres due to health complications. As not all of the animals were tagged, it was not always possible to gather accurate data, such as their precise age. Although all eagles were found in the territory of Poland in the years 2010-2016, several individuals might have come from eastern Germany. This was definitely the case with a 1-year-old female.

After a preliminary inspection of the dead birds they underwent radiological tests. Two methods of imaging were used: computer tomography and digital radiography. CT used for imaging was fully automated (AnimageFidex) using a cone-beam computed tomography (CBCT). Digital radiography was made using an EXAMION DR Maxivet Co. X-ray that applied tube voltage of $46 \mathrm{kV}$ in the tube current-exposure time of $10 \mathrm{mAs}$. Then the bones of the birds were extracted and subsequently assessed for macroscopic osteological lesions. During examination of the bones' condition, we followed the observations of Bradshaw et al. [17] regarding osteochondrosis and degenerative joint disease. In the case of osteomyelitis we used the study of Wideman [18].

Bone fractures that resulted from accidental collisions and led to the bird's death were not taken into account. It was assumed that in some of the birds the bones were morphologically healthy before the accident. Therefore, pathological changes in the bones were diagnosed in $14(38 \%)$ out of the 37 animals analysed.

Due to suspected osteochondrosis, a microscopic examination was additionally conducted in two cases using a standard histological imaging technique of haematoxylin and eosin stain (H\&E).

\section{Results and Discussion}

Macroscopic bone lesions of different types were found in 14 out of 37 birds, excluding fractures caused by collisions that were the immediate cause of death. 


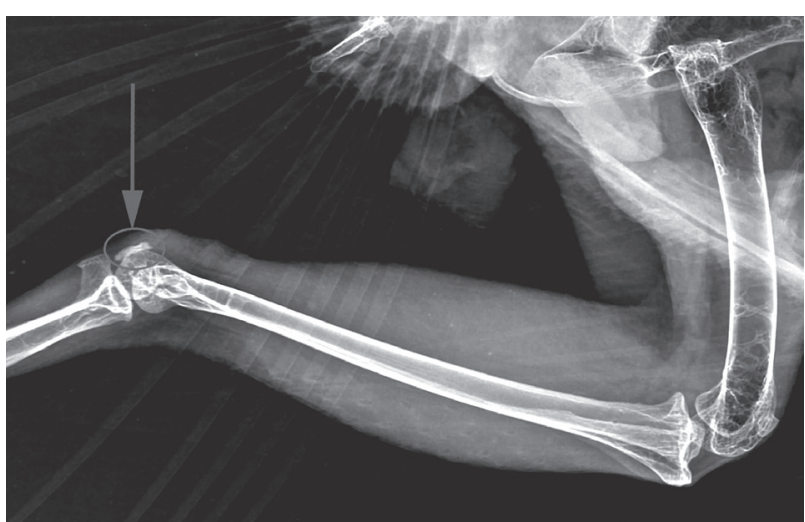

Fig. 1. A fragment of a pelvic limb of a four-year-old male. The chip in the ankle joint of the caudal surface of the trochlea of tibiotorsal bone.

However, in some of the birds more than one pathological change in different bones of the skeleton was found.

\section{Osteochondritis Dissecans}

Osteochondritis dissecans (OCD) is a type of osteochondrosis that affects both mammals and birds. It is considered a multifactorial disease, with hereditary and nutritional factors playing a significant role [19-21]. Since excessive intakes of calcium and energy are among the main factors for the development of the disease, it often affects mammals and birds kept on farms where fast growth is stimulated [22-24]. Yet another important factor conducive to the disease are distortions of hormonal balance reflected in the growth rate as well as cartilage and bone maturation. As the disease affects joints, injuries and biomechanical factors also seem to

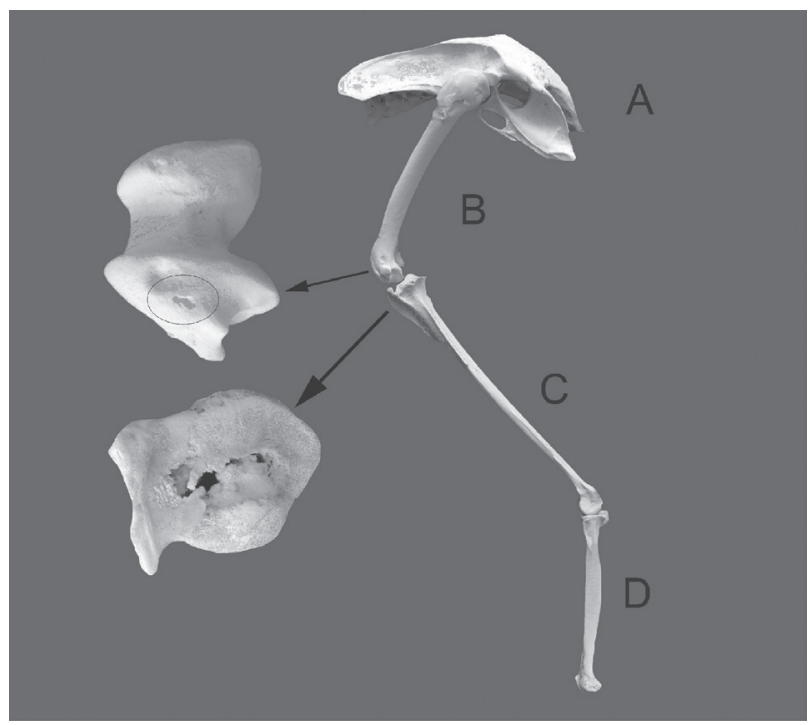

Fig. 2. The location of OCD in the pelvic limb. The arrows indicate the adjacent epiphyses of the knee joint with pathological changes. A) Pelvis, B) Femur, C) Tibiotarsus, D) Tarsometatarsus. play an important role in its development [25-29] and appear to be of primary importance when analysing the disease in wild birds.

Lesions characteristic of OCD were found in 6 individuals. In five cases they were located in the knee joint, and only in one case was it in the ankle joint (Fig. 1). In one bird, lesions of the knee joint were present in both legs. More severe changes were observed on the proximal articular surface of the tibiotarsal bone. The changes on condyles of femur were weaker or absent (Fig. 2). Consequently, it seems that the tibiotarsal bone is particularly vulnerable to changes typical of OCD. These observations are partly in line with the findings of Rothschild and Panza [30], who proved that skeletal pathology of this bone is very common in wild birds. However, these authors mostly described lesions in the distal epiphysis, which is why pathological lesions in many species of birds appear in the tibiotarsal-tarsometatarsal (ankle) joint area [31], whereas in the white-tailed eagles examined here they were found more often in the femorotibial (knee) joint. This might result from the joint being extremely overloaded when the eagle hunts aquatic birds and fish swimming close to the water surface. The attacking bird swoops down on the water surface with straight knee joints and then bends with great force while catching the prey. Importantly, since only $10-20 \%$ of the attacks are successful, the bird has to make repeated attempts to achieve its goal. In consequence, its knee joints are exposed to a considerable number of strong blows against the water [2]. Therefore, it cannot be ruled out that the biomechanics of hunting on water surfaces may be a factor conducive to osteochondral lesions.

The described lesions on bones were observed macroscopically, yet in two cases we extended our observations to microscopic analyses. In one of the individuals with suspected OCD, histology revealed a clear thinning in the articular cartilage of the proximal epiphysis of tibiotarsal bone (Figs 3a-b), while no defect in the subchondral bone was observed. It seems, however, that the thinning of cartilage is the first symptom of lesions due to overload. Since analyses of this type were conducted in mammals, one may expect an analogy [32]. The other bird was regarded as a control. Compared to the previous individual, it had a markedly thicker articular cartilage in the same location (Fig. 3c).

\section{Osteophytes, Osteoarthritis, and Osteomyelitis}

Apart from the disease described above, the most common problem is the presence of osteophytes. They were found in the bones of the axial skeleton, as well as pelvic limb bones and, less frequently, wing bones. However, when classical screening in the x-ray test was used, the presence of the osteophyte might not be visible in some cases. The $\mathrm{CT}$ usage gives more detailed results (Fig. 4).

In three cases, osteophytes formed on the sternum. In every instance, they formed on the apex of carina on both sides (Fig. 5a). There was also one case of osteophytes on 

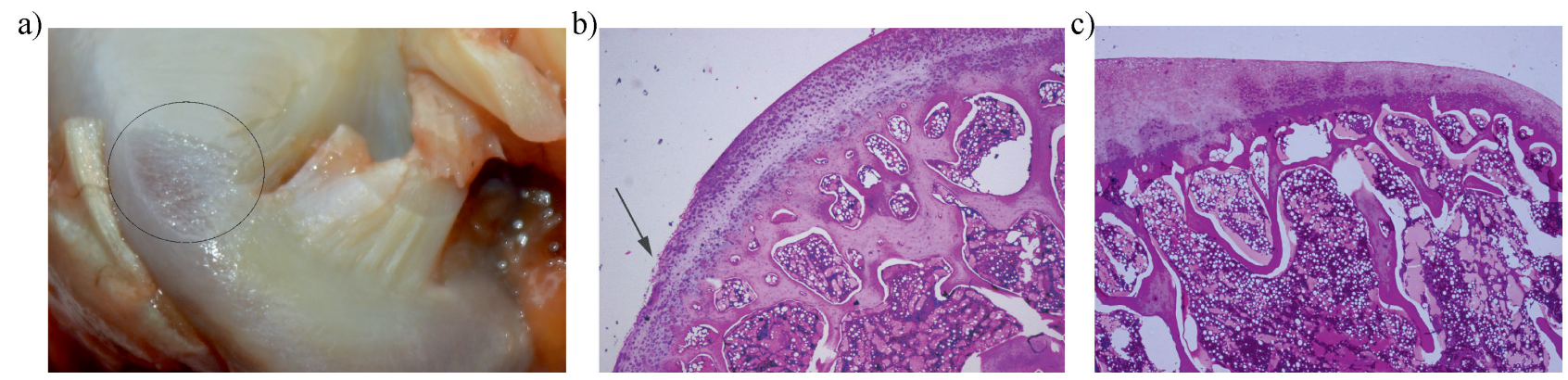

Fig. 3. a) Preliminary lesions of fibrosis and loss of articular cartilage in proximal epiphysis of tibiotarsus in a nine-year-old specimen. b) Haematoxylin and eosin stain (H\&E) - the arrow indicates thinning in the articular cartilage c) H\&E of the same place in a control specimen.

the articular surface of the clavicle, which could suggest osteoarthritis (Fig. 5b). This bird also had smaller osteophytes on the fibula. Osteophytes were found in three cases in the tarsometatarsal bone and sometimes the neighbouring phalanges (Fig. 5c). Excessive bone formation was also observed in the tibiotarsaus in two birds. Changes in the bone structure were moderate in one bird and severe in the other. In the latter case we diagnosed acute osteoarthritis with necrosis of the neighbouring epiphyses of the tibiotarsal-tarsometatarsal joint (Fig. 6). The joint was completely deformed as a result of the lesions. This case is more proof that the tibiotarsal bone and especially its epiphyses are structures that undergo pathological changes most frequently. However, it cannot be excluded that the primary cause of the changes in that particular bird was an accidental collision or mechanical trauma that subsequently led to osteoarthritis. Osteophytes on the tibiotarsal bone in wild birds were observed by Rothschild and Panza [33], who also pointed out, however, that various species of birds are not equally prone to such diseases. Interestingly, they observed relatively few cases of bone diseases in Accipitriformes.

Our research revealed that there were significantly fewer lesions involving excessive bone formation on wing

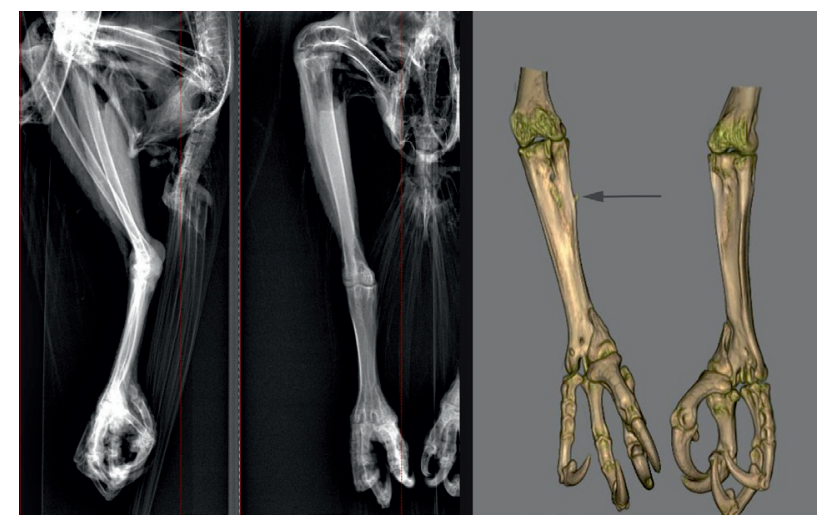

Fig. 4. On the left, the x-ray of pelvic bones of an adult female. On the right, CT scan of the same individual. The arrow points to a sharp osteophyte on the left tarsometatarsus which is located on the medial side. bones. They appeared mostly in the autopodial segments, i.e., on the carpometacarpus and the proximal phalanx of the major digit. In one bird such lesions were present in both wings; in the remaining two cases osteophytes were observed on the carpometacarpus - especially near the carpal joint. They were lesions typical for osteoarthritis and could have appeared as a consequence of a mechanical injury (Fig. 5d).

Very strong changes with visible pathological bone formation were found in the tarsometatarsal bone. The eagle had a double fracture of this bone (Fig. 7). The first incident occurred in his natural habitat. The bird was found and transported to the rehabilitation unit, where the bone healed but later fractured again in the same place. The macroscopic presentation was typical of osteomyelitis, which could be linked to a bacterial infection [34]. Stalker et al. [35] concluded that osteomyelitis and osteoarthritis may co-occur, which is associated with the presence of the Enerococcus cecorum bacteria. A correlation between the presence of these bacteria and osteoarthritis and bone necrosis was also found by Kense and Landman [36]. Although the changes presented by these authors concerned domestic chickens, their findings are similar to the changes observed in our study.

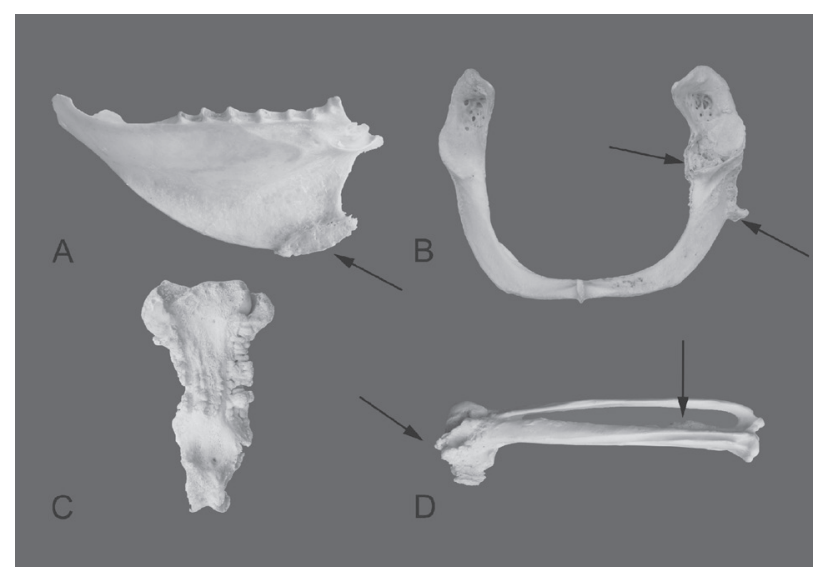

Fig. 5. Examples of osteophytes A) Sternum, B) Clavicle, C) Proximal phalanx of the pelvic limb, D) Carpometacarpus. 


\section{Other Types of Bone Diseases}

Among other pathologies found, there was a case of lesions typical of osteosarcoma in a 2-year-old specimen. A definite diagnosis would require histopathological examination, but in this case we had only the bird's skeleton. The strongest lesions were localised at the distal metaphysis of the tibiotarsal bone area (Fig. 8). Although this neoplasm is rarely observed in birds, it

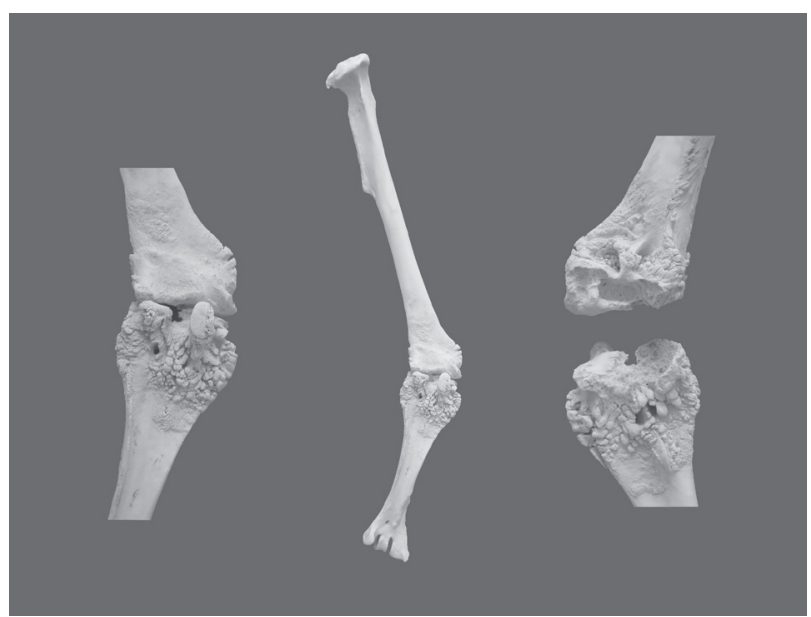

Fig. 6. Regressive and proliferative changes in the ankle joint accompanying chronic inflammation. Centrally - tibiotarsus and tarsometatarsus of the left limb, caudal aspect. On the left - a close-up of the ankle joint. On the right - a view of degenerated articular surfaces, cranial aspect.

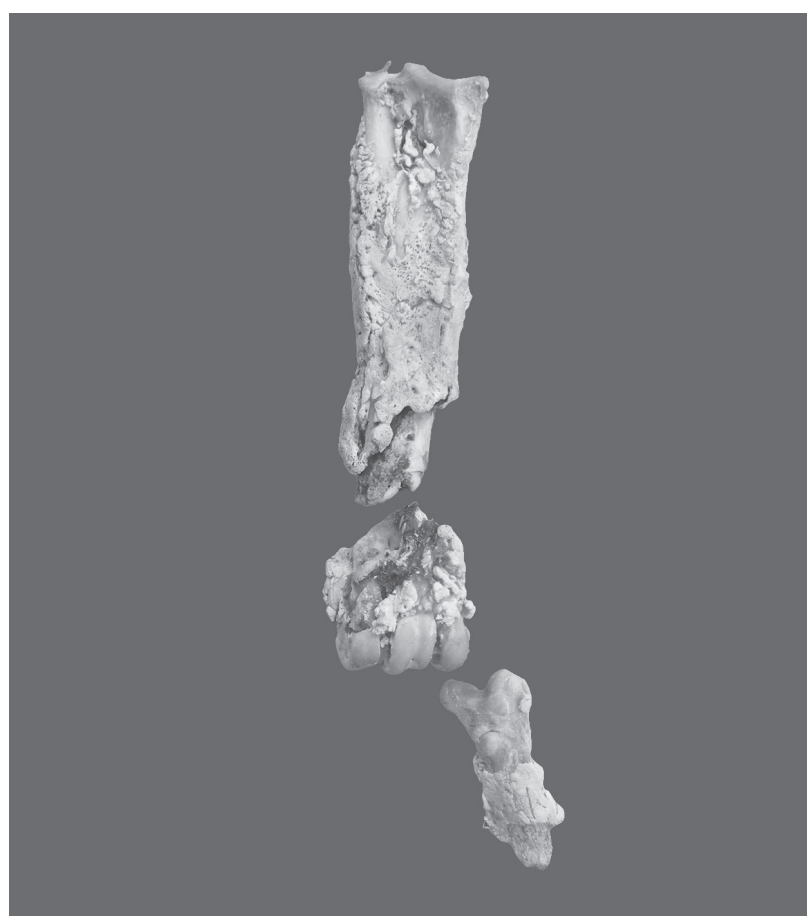

Fig. 7. Osteomyelitis. Pathological fracture with clear bone lysis on the diaphysis of the tarsometatarsal bone. Below - the proximal phalanx with excessive bone formation. has been described both in poultry and in some wild species [37-38]. Osteosarcoma may affect both the axial and appendicular skeleton. It is worth noting that in the white-tailed eagle it is found in the tibiotarsal bone. Interestingly, osteosarcoma has been recently described with regard to the same bone in the ring-necked dove [39]. As regards the hypothetical causes of osteosarcoma in birds, poisoning with heavy metals is a likely factor, particularly in view of the fact that the carcinogenic effects of these elements has been confirmed in mammals [40]. As far as the white-tailed eagle is concerned, the prime suspects are lead and cadmium. The danger of lead poisoning is emphasised by Falandysz et al. [41], Kalisińska et al. [42], and Nadjafzadeh et al. [43]. However, another fact that may be of particular importance here is that cadmium accumulates in the bodies of fish, which are consumed in large amounts by the white-tailed eagle, often in the form of carrion. Numerous publications, such as the research on carp (Cyprinus carpio) by Kovarova et al. [44], have confirmed that the danger truly exists. Cadmium has been long considered an important factor in the formation of this type of carcinoma. Research conducted mostly in laboratory mammals has shown that cadmium distorts calcium metabolism and decreases osteoblast differentiation. Moreover, it weakens the mechanical properties of the bone tissue, for example by reducing its vascularization [45-48]. These factors are not only conducive to osteosarcomagenesis, but may also explain a predisposition toward OCD. It is worth emphasising that large predators, including eagles, are at the top of the food chain, which explains why they may accumulate the largest amount of cadmium coming from contaminated water. This accumulation increases across the food chain, beginning with zooplankton, through smaller fish, to large ones [49].

As regards other observed osseous changes, one individual with a deformed humerus attracted our particular interest (Fig. 9). The bird had other lesions,

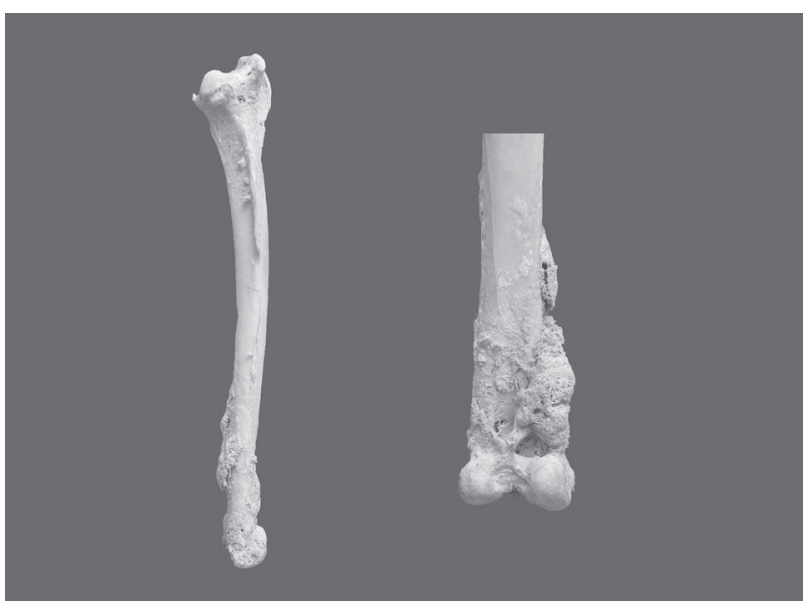

Fig. 8. Proliferative changes in the metaphyseal area, characteristic of osteosarcoma. On the left -the right tibiotarsus, lateral aspect. On the right - enlargement of the distal extremity, cranial aspect. 


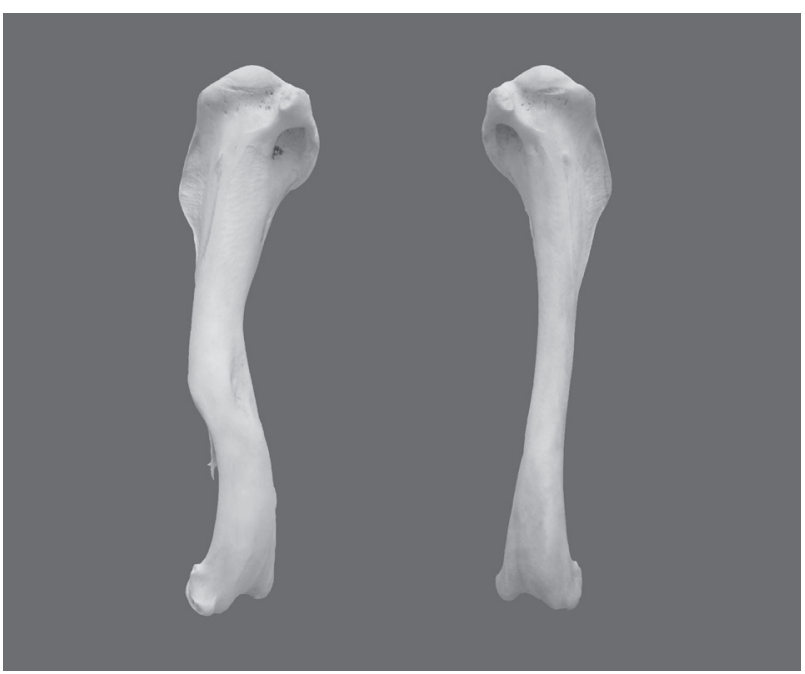

Fig. 9. Distorted left humerus in comparison with the healthy bone on the other side, caudal aspect.

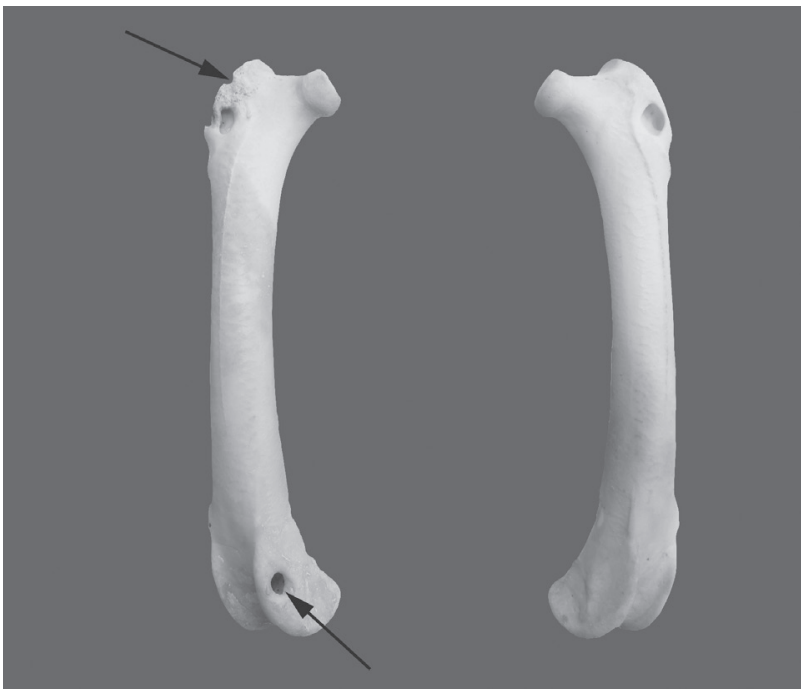

Fig. 10. Lesions on the right femur indicated with arrows, cranial aspect.

such as osteophytes on the sternum and on certain pelvic limb bones. All evidence suggests that the eagle was a victim of collision, as it was unable to fly in its natural habitat when it was found. It spent the rest of its life in a zoological garden. Humerus deformation in that specimen did not result from developmental changes, but post-fracture bone healing.

The last case was a bird with changes in the femoral bone (Fig. 10). These lesions, although found close to the hip joint, affected only the trochanter of femur. Moreover, reverse changes in the form of bone necrosis caused stenosis of the pneumatic foramen. The foramen is where the diverticulus of abdominal air sac enters the femoral bone. Interestingly, a foramen appeared on the distal epiphysis of this bone on the medial side, which should be regarded as an anomaly, as it is not to be found on the healthy femur of a bird.

\section{Conclusions}

1. The contemporary white-tailed eagle population in Central Europe is highly exposed to osseous diseases.

2. Alterations caused by osteochondritis dissecans affect especially the bones involved in the construction of the knee joint. The strongest bone losses were observed on the proximal articular surface of the tibiotarsal bone. Somewhat less susceptible to changes is the distal epiphysis of femur.

3. Often observed are osteophytes, some of which are a sign of the presence of osteoarthritis. Excessive bone formation occurs more frequently on the bones of the pelvic limbs, and less frequently on the bones of the wings. There are cases of osteophytes found on the sternum.

4. One case of bone lesions typical of osteosarcoma and single cases of humerus deformity and bone necrosis of the trochanter of femur were identified.

\section{Conflict of Interest}

The authors declare no conflict of interest.

\section{References}

1. HAUFF P., MIZERA T., CHAVKO J., DANKO S., EHMSEN E., HUDEC K., PROBST R., VERA F. Verbreitung und Dichte des Seeadlers Haliaeetus albicilla in sieben Ländern Mitteleuropas. Vogelwarte 45, 376, 2007.

2. MIZERA T. White-tailed Eagle. Świebodzin: Wydawnictwo Lubuskiego Klubu Przyrodników (in Polish with English summary), 195, 1999.

3. KRÜGER O., GRÜNKORN T., STRUWE-JUHL B. The return of the white-tailed eagle (Haliaeetus albicilla) to northern Germany: Modelling the past to predict the future. Biological Conservation 143, 710, 2010.

4. SÁNDOR A.D., ALEXE V., MARINOV, DOROŞENCU A., DOMŞA.C., KISS B.J. Nest-site selection, breeding success, and diet of white-tailed eagles (Haliaeetus albicilla) in the Danube Delta, Romania. Turk. J. Zool. 39, 300, 2015

5. TODOROV E., DASKALOVA G., SHURULINKOV P. Current Breeding Distribution and Conservation of Whitetailed Eagle, Haliaeetus albicilla (L.) in Bulgaria. Acta Zoologica Bulgarica 67, 3, 2015.

6. HORVÁTH Z. White-tailed Eagle (Haliaeetus albicilla) populations in Hungary between 1987-2007. Denisia 27, 85, 2009.

7. BELKA T., HORAL D. The White-tailed Eagle (Haliaeetus albicilla) in the Czech Republic. Denisia 27, 65, 2009.

8. FALANDYSZ J., ICHIHASHI H., MIZERA T., YAMASAKI S. Mineral composition of selected tissues and organs of White-tailed Sea Eagle. Roczniki Panstwowego Zakladu Higieny 51, 1, 2000.

9. KRONE O., LANGGEMACH T., SÖMMER P., KENNTNER N. Causes of mortality in White-tailed Sea Eagles from Germany. In: Helander B, Marquiss M, Bowerman W (eds), Sea Eagle 2000. Proceedings from an international conference at Bjorko, Sweden. Swedish Society for Nature Conservation, 211, 2003. 
10. BRZÓSKA M.M., MONIUSZKO-JAKONIUK J. Interactions between cadmium and zinc in the organism. Food and Chemical Toxicology 39, 967, 2001.

11. MARTELLI A., POUSSELET E., DYCKE C., BOURON A., MOULIS J.M. Cadmium toxicity in animal cells by interference with essential metals. Biochemie 88, 1807, 2006.

12. ANDERWALD D. Causes of mortality birds of prey and owls on the basis of data analysis in "Records of dead and weakened birds" run by Eagle Conservation Committee. Studia i Materialy Centrum Edukacji Przyrodniczo-Lesnej 11, 125, 2009.

13. LOSS S.R., WILL T., MARRA P.P. Estimates of bird collision mortality at wind facilities in the contiguous United States. Biological Conservation 168, 201, 2013.

14. PAGEL J.E., KRITZ K.J., MILLSAP B.A., MURPHY R.K., KERSHNER E.L, Covington S. Bald Eagle and Golden Eagle Mortalities at Wind Energy Facilities in the Contiguous United States. Journal of Raptor Research, 47 (3), 311, 2013.

15. ZIMMERLING J.R., POMEROY A.C., D'ENTREMONT M.V., FRANCIS C.F. Canadian Estimate of Bird Mortality Due to Collisions and Direct Habitat Loss Associated with Wind Turbine Developments. Avian Conservation and Ecology 8 (2), 10, 2013.

16. KRONE O., SCHARNWEBER C. Two White-tailed Sea Eagle (Haliaeetus albicilia) collide with wind generators in northern Germany. Journal of Raptor Research 37, 174, 2003.

17. BRADSHAW R.H., KIRKDEN R.D., BROOM D.M. A review of the aetiology and pathology of leg weakness in broilers in relation to their welfare. Avian and Poultry Biology Reviews. 13: 45, 2002.

18. WIDEMAN R.F. Bacterial chondronecrosis with osteomyelitis and lameness in broilers: a review. Poult Sci. 95 (2), 325, 2016.

19. McCOY A.M., TOTH F., DOLVIK N.I., EKMAN S., ELLERMANN J., OLSTAD K., YTREHUS B., CARLSON C.S. Articular osteochondrosis: a comparison of naturallyoccurring human and animal disease. Osteoarthritis and Cartilage 21, 1638, 2013.

20. MENDOZA L., LEJEUNE J.P., CAUDRON I., DETILLEUX J., SANDERSEN C., DELIEGE B., SERTEYN D. Impact of feeding and housing on the development of osteochondrosis in foals-A longitudinal study. Prev. Vet. Med. 127, 10, 2016.

21. TÓTH F., TORRISON J.L., HARPER L., BUSSIERES D., WILSON M.E., CRENSHAW T.D., CARLSON C.S. Osteochondrosis prevalence and severity at 12 and 24 weeks of age in commercial pigs with and without organiccomplexed trace mineral supplementation. J. Anim. Sci. 94 (9), 3817, 2016.

22. BIEŻYŃSKI J., SKRZYPCZAK P., PIĄTEK A., KOŚCIÓŁEK N., DROŻDŻYŃSKA M. Assessment of treatment of Osteochondrosis dissecans (OCD) of shoulder joint in dogs - the results of two years of experience. Polish Journal of Veterinary Sciences 2, 2850, 2012.

23. LEPEULE J., BAREILLE N., ROBERT C., EZANNO P., VALETTE J.P., JACQUET S., BLANCHARD G., DENOIX J.M., SEEGERS H. Association of growth, feeding practices and exercise conditions with the prevalence of Developmental Orthopaedic Disease in limbs of French foals at weaning. Prev. Vet. Med. 89 (3-4), 167, 2009.
24. SCHMIDT R.E., REAVILL D.R., PHALEN D.N. Pathology of Pet and Aviary Birds, Second Edition. (C) JohnWiley \& Sons, Inc., pp 206-218, 2015.

25. BUGGEMAN M., VAN VYNCKT D., VAN RYSSEN B., BOLLN G., CHIERS K., GIELEN I., DE ROOSTER $H$. Osteochondritis dissecans of the humeral head in two small-breed dogs. Veterinary Record 166, 139, 2010.

26. LAUNAY F. Sports-related overuse injuries in children. Orthop. Traumatol. Surg. Res. 101 (1 Suppl), 139, 2015.

27. PFEIFER C.G., KINSELLA S.D., MILBY A.H., FISHER M.B., BELKIN N.S., MAUCK R.L., CAREY J.L. Development of a Large Animal Model of Osteochondritis Dissecans of the Knee. The Orthopaedic Journal of Sports Medicine 3 (2), 1, 2015.

28. TARABELLA V., FILARDO G., DI MATTEO B., ANDRIOLO L., TOMBA P., VIGANO A., MARCACCI M. From loose body to osteochondritis dissecans: a historical account of disease definition. Joints. 4 (3), 165, 2016.

29. VAN BERGEN C.J., VAN DEN ENDE K., TEN BRINKE B., EYGENDAAL D. Osteochondritis dissecans of the capitellum in adolescents. World. J. Orthop., 7 (2), 102, 2016.

30. ROTHSCHILD B.M., PANZA R. Epidemiologic assessment of trauma-independent skeletal pathology in non-passerine birds from museum collections. Avian Pathology 34, 212, 2005.

31. ROTHSCHILD B.M., RÜHLI F.R. Comparative Frequency of Osseous Macroscopic Pathology and First Report of Gout in Captive and Wild-caught Ratites. Journal of Veterinary Medicine A 54, 265, 2007.

32. KOMOSA M., ŁAZOWSKI S., WŁODAREK J., KOWALCZYK K., CHARUTA A., ZDUN M. Gross and histological evaluation of early lesions of navicular bone and deep digital flexor tendon in horses. Bulletin of the Veterinary Institute in Pulawy 58, 87, 2014.

33. ROTHSCHILD B.M., PANZA R. Osteoarthritis is for the birds. Clinical Rheumatology 25, 645, 2006.

34. WIDEMAN R.F. Bacterial chondronecrosis with osteomyelitis and lameness in broilers: a review. Poultry Science 95, 325, 2016.

35. STALKER M.J., BRASH M.L., WEISZ A., OUCKAMA R.M., SLAVIC D. Arthritis and osteomyelitis associated with Enterococcus cecorum infection in broiler and broiler breeder chickens in Ontario, Canada. Journal of Veterinary Diagnostic Investigation 22, 643, 2010.

36. KENSE M.J., LANDMAN W.J.M. Enterococcus cecorum infections in broiler breeders and their offspring: molecular epidemiology. Avian Pathology 40, 603, 2011.

37. DITTMER K.E., FRENCH A.F., THOMPSON D.J., BUCKLE K.N., THOMPSON K.G. Primary bone tumors in birds: a review and description of two new cases. Avian Diseases 56, 422, 2012.

38. FORDHAM M., ROSENTHAL K., DURHAM A., DUDA L., KOMÁROMY A.M. Intraocular osteosarcoma in an Umbrella Cockatoo (Cacatua alba). Veterinary Ophthalmology 13, 103-108, 2010.

39. LAMB D., REAVILL D., WOJCIESZYN J., SITINAS N. Osteosarcoma of the Tibiotarsus With Possible Pulmonary Metastasis in a Ring-necked Dove (Streptopelia risoria). Journal of Avian Medicine and Surgery 28, 50, 2014.

40. JONES K.B. Osteosarcomagenesis: Modeling Cancer Initiation in the Mouse. Hindawi Publishing Corporation Sarcoma, Article ID 694136, 10 pages doi:10.1155/2011/694136, 2011. 
41. FALANDYSZ J., JAKUCZUN B., MIZERA T. Metals and organochlorines in four female white-tailed eagles. Marine Pollution Bulletin 19, 521, 1988.

42. KALISIŃSKA E., SALICKI W., JACKOWSKI A. Six Trace Metals in White-Tailed Eaagle from Northwestern Poland. Polish Journal of Environmental Studies 15, 727, 2006.

43. NADJAFZADEH M., HOFER H., KRONE O. Lead exposure and food processing in white-tailed eagles and other scavengers: an experimental approach to simulate lead uptake at shot mammalian carcasses. European Journal of Wildlife Research 61, 763, 2015.

44. KOVAROVA J., KIZEK R., ADAM V., HARUSTIAKOVA D., CELECHOVSKA O., SVOBODOVA Z. Effect of cadmium chloride on metallothionein levels in carp. Sensors (Basel). 9 (6), 4789, 2009.

45. ANGLE C.R., THOMAS D.J., SWANSON S.A. Toxicity of cadmium to rat osteosarcoma cells (ROS 17/2.8): protective effect of 1 alpha,25-dihydroxyvitamin D3. Toxicology and Applied Pharmacology 103, 113, 1990.
46. DURANOVA H., MARTINIAKOVA M., OMELKA R., GROSSKOPF B., BOBONOVA I., TOMAN R. Changes in compact bone microstructure of rats subchronically exposed to cadmium. Acta Veterinaria Scandinavica 56, 64, 2014.

47. LONG G.J. Cadmium perturbs calcium homeostasis in rat osteosarcoma (ROS 17/2.8) cells; a possible role for protein kinase C. Toxicology Letters 91, 91, 1997.

48. SOSA-GARCIA B., GUNDUZ V., VAZQUEZ-RIVERA V., CRESS W.D., WRIGHT G., BIAN H., HINDS P.W., SANTIAGO-CARDONA P.G. A role for the retinoblastoma protein as a regulator of mouse osteoblast cell adhesion: Implications for osteogenesis and osteosarcoma formation. Plos One 5 (11), e13954. doi:10.1371/journal.pone.0013954, 2010.

49. LEVIT S.M. A literature review of effects of cadmium on fish. Centre for Science in Public Participation, Bozeman, Montana pp 15, 2010. 